\title{
Concept of an "Ideal Europe" in the Philosophical Discourse during World War I (1914-1918): British Rationalism versus German "Individualism"
}

\author{
Sergiy Stelmakh \\ Doctor of Historical Sciences (Dr. Hab. in History), Professor, \\ Taras Shevchenko National University of Kyiv \\ (Kyiv, Ukraine) \\ E-mail: sergiy-stelmakh@ukr.net \\ https://orcid.org/0000-0002-0795-8356
}

\begin{abstract}
Sabina Kotova
Historian, Research Department, Taras Shevchenko National University of Kyiv

(Kyiv, Ukraine)

E-mail: kotova_sabina@ukr.net

https://orcid.org/0000-0001-9275-0615
\end{abstract}

Stelmakh, Sergiy and Sabina Kotova (2020) Concept of an "Ideal Europe" in the Philosophical Discourse during World War I (1914-1918): British Rationalism versus German “Individualism." Future Human Image, Volume 13, 2020: 94-101. https://doi.org/10.29202/ fhi $/ 13 / 10$

The article addresses the issues of involvement of UK and German philosophers in the "war of cultures" during World War I (1914-1918). Over the course of the war, humanities scholars used opinion-based journalism to formulate certain views and opinions, boost the morale of the army and the public, and call readers to action. Philosophy was one of the ideological battlegrounds, which meant an antagonism between English rationalism and German individualism. The authors analyze the conceptual principles of the German "idea of freedom," "Germanism" ("Deutschtums"), and their criticism by British philosophers. The article sheds light on the idea of an "ideal Europe" put forward by German thinkers as a worldview construct designed to overcome the European cultural crisis.

Keywords: World War I (1914-1918), rationalism, idealism, individualism, "idea of freedom," "ideal Europe," "Germanism"

Received: March 1, 2020; accepted: March 25, 2020

(C) Stelmakh, Sergiy, 2020

(C) Kotova, Sabina, 2020 


\section{Introduction}

World War I was a "total war" where ideological battles became just as important as armed combat. Contemporary historiographers point out that the phenomenon of an "info war" first originated during that time. Over the course of the war, humanities scholars used opinion-based journalism to formulate certain views and opinions, boost the morale of the army and the public, and call readers to action. They helped instill in the public consciousness a hostile attitude toward enemies at the level of "historical culture," for since the beginning of the $20^{\text {th }}$ century, "construction of the past" stopped being the exclusive prerogative of professional scholars. Wartime periodicals became the dominant mass media outlet and proved to be a powerful tool in the matter of "portrayal of the enemy." Opinion-based journalists wrote in layman's terms and offered society "images of the past" in the form of "narrative templates," thereby helping to instill in the mass consciousness the stereotypes that benefited the government at the time.

Philosophy became yet another ideological battleground that occupied a notable place in the wartime social and humanities discourse (Hoeres, 2004; Riebel, 2014). Effectively, it was all about the continuation of a long-standing antagonism between "British empiricism" (which searched for reality in the empirical world, thereby laying the groundwork for rationalism in day-to-day life) and "German idealism."

\section{Idealistic Philosophy and German "Idea of Freedom"}

British philosophers, particularly John Henry Muirhead, a philosophy professor at Birmingham University, were quite reserved in their criticism of the fundamental basics of German philosophy, especially its idealistic components, giving credit to Kant: "There can be no doubt that Kant's ideas had a profound influence on the politics of the time. In spite of Carlyle, Frederick the Great is not a hero in England. Yet, on the whole, the spirit of his reign may be said to have been the spirit of Kant" (Muirhead, 1915a: 8). Hegel's concept of the state as true "freedom" and as a powerful component of international politics is to this day being incorrectly interpreted as the wellspring of Prussian militarism. The British philosopher contended that the formulation "war is a continuation of politics" does not stem from the provisions of Hegel's philosophy, since the German thinker believed that "the continuation of politics is art, science, religion all that goes to make what Aristotle called the good life for the full development of which the State is the essential condition" (Muirhead, 1915b: 36-37). The British author is certain, however, that Hegel's ideas are not where one should look for the wellspring of Prussian militarism; instead, it is to be found in the reaction against the idealist philosophy that was touched off after his passing in 1831 . The combination of Feuerbach's materialism with Marxism and Darwinism with its "natural selection" theory and the transposition of these ideas onto society gave rise to Social Darwinism. "The result was that, going along with the material expansion and the devotion to the special sciences it evoked, we have a philosophy which sought to invert the old order, and to read the body and matter where it had read mind and spirit" (Muirhead, 1915b: 51). A prominent representative of this philosophy is Max Stirner, founder of the concept of individualistic anarchism, whose work The Ego and His Own (1844) was called "most radical and subversive."

Ernst Troeltsch viewed the concept of "the individual" as the primary philosophical category of German national philosophy since the times of Kant, Fichte, and Schleiermacher, which was fundamentally developed by contemporary German philosophers Dilthey, Windelband, Rickert, Simmel, and others. "Here "the individual" does not mean an opposition to society 
or a type or the mass or the totality („Gesamtzusammenhang”); it means an opposition to the abstract nature of common laws, and so the uniqueness, one-of-a-kind and special nature of historical objects can be an epoch, a cultural trend, a state, a people, social groups, classes, and separate individuals" (Troeltsch, 1916b: 9).

It was from these very intentions that German intellectuals began elaborating the German "idea of freedom." Ernst Troeltsch contended that the war resulted from the spiritual isolation of Germany - ahead of the war and at its outbreak - from European society with its rationalism and utilitarianism, which forced it to resort to self-reflection and self-realization. "In the course of this introspection, an idea of freedom was revealed to us. This idea is actually different from the idea of freedom in the sense of Western nations - both from the individualism of the English master and from the exciting idea of equality that originated from the theory of human rights. Our idea of freedom is founded not in puritanism and not in Rousseau's teaching, but in the eternal German spirit." Rational individualism is contradistinguished from German "individualism of the spirit of commonness," which is understood as civic responsibility for decision-making, an individual responsibility for "the whole, the freedom of the feeling of commonness and discipline; notably, both the former and the latter are founded on the willingness to sacrifice oneself in the name of ideas, and is therefore closely linked with our entire religious-ethical essence that is starkly different from that of the English and the French..." (Troeltsch, 1916a: 620-622).

Criticism of German philosophy by British philosophers primarily targeted Hegel's idea of a "strong stage" as the foundation of Prussian militarism. It did not touch on the key categories of the idealistic philosophy, which can be attributed to its quite powerful influence in the European intellectual domain. Instead, their criticism targeted the ideas of Friedrich Nietzsche, which spread through Europe in the early $20^{\text {th }}$ century despite eliciting a controversial response. John Muirhead, for one, pointed out that Nietzsche's works said a great deal about the benefits of war and suggested reading them more in-depth "from start to end": "Yet even on the level of the lower interpretation, it would be difficult to find in his teaching anything that could be taken as an incentive to a policy of national violence." On the contrary, already in 1873, the philosopher spoke out against the Prussian military system, and a decade later criticized then-contemporary German philosophy, education, "idolaters of the nation," etc. It is a different matter that these ideas of "another Nietzsche" went unnoticed, while the ideas of the Superman and the "blond beast" gained traction in German society (Muirhead, 1915b: 79-80). Meanwhile, in the British popular discourse Friedrich Nietzsche alongside Heinrich Treitschke were portrayed as the chief carriers of German militarism, chauvinism, and amorality, with the words of Scottish writer, critic and translator William Archer becoming a key recurrent message: "In a genuine sense, it is the philosophy of Nietzsche that we are fighting." The author proceeded from the indisputable premise that the world war became a continuation of Germany's militaristic and spiritual development since 1871, "and Nietzsche, more or less unconsciously I repeat, has provided for the average, intelligent, uncritical public — the Culture-Philistines as he himself called them — a philosophic justification of the spiritual development." The pamphlet is overflowing with quotes from works by the German philosopher. Their chief purpose was to persuade British readers that their author popularized a human-hating concept caused by a childhood mental trauma that affected all of his subsequent work. In the opinion of William Archer, the most harmful attribute of Nietzsche's philosophy was his concept that divided mankind into a race of masters and a race of slaves. The "master morality" succeeded in begetting a flourishing brood of "super-snobs," who abound in the high places of Pan-Germanism, military, political, and journalistic (Archer, 1915: 5, 24). 


\section{"Culture Crisis" in the Intellectual Discourse}

Barbarian warfare methods cultivated by opponents in the battlefield, such as the use of weapons of mass destruction, murders of civilians, and destruction of landmarks of history and culture, brought the issue of a "culture crisis" to the foreground of the intellectual discourse. Gerhart Hauptmann, famous playwright and writer, who won the Nobel Prize in 1912, published an article titled Against Untruth in September 1914, in which he claimed that Germany was waging a "defensive war" ("Verteidigungskrieg"). This war was unleashed not by Asians, the Japanese, the Mongols, or the Turks, who had been waging war on European culture for many centuries, but by the English, who - "with their Ph.D. diplomas from Oxford University" — are calling the Germans barbarians. "They are calling Weimar a barbarian city - a place where Goethe, Gerder, Wilan, and others worked to humanize the world." Gerhart Hauptmann underscored the close connection between German and English spiritual cultures as exemplified by Shakespeare and long-standing dynastic ties between both nations, whereas the "bloody duel" can only undermine the humanistic foundations of European culture. "Barbarian Germany" — the write wrote ironically — was not just a country of European culture but also the first nation in Europe with its ramified and effective social security institutions. "We want to be and would rather remain German barbarians, in whose midst the women and children of our opponents genuinely enjoy our hospitality" (Hauptmann, 1914: 7).

German sociologist and philosopher Georg Simmel took this issue to the level of an intellectual discussion in his article Idea of Europe in 1915. In his opinion, one of the horrible consequences of the world war was the destruction of the "unitary mental essence to which we refer as Europe." Georg Simmel was confident that Europeanism was not opposed to nationalism and was not internationalism, which was the fear of most Germans, since an "ideal" Europe is a place of spiritual values that are inherent in every cultured person irrespective of their ethnicity, meaning that both Goethe and Beethoven, Schopenhauer and Nietzsche belong to the cohort of its creators. For this reason, Europeanism is not merely an external supplement of Germanism but its internal spiritual component (Simmel, 1917b: 69). Mostly, it was an attempt at defending the German culture against accusations spread by intellectuals of Great Britain and Russia, and substantiating an opinion that the European cultural landscape was unimaginable without German culture of the $18^{\text {th }}-19^{\text {th }}$ centuries.

Fritz Ringer asserted that during World War I, German intellectuals tried their hardest to downplay the successes of England rather than France. They treated the latter favorably and instead channeled the energy of their polemic onslaughts at the English. This was partly attributable to a long-standing naval rivalry and the fact that England was the number-one enemy on the battlefield. However, the roots of this antagonism went deeper still. "England was the chief example of a highly industrialized and politically developed country, and English society was just like Germany could become soon enough, no matter how the Mandarins tried to interfere with this." They tried to convince primarily their own German society that English concepts of freedom were unacceptable for German traditional cultural individualism, since they foster instincts of consumers and a sense of antagonism against the state; the power of the public opinion suppresses genuine individuality in the cultural environment, leaving only the general mediocrity, against the background of which the 'merchant mindset' rules the individual and spiritual life (Ringer, 2008: 224). It was no accident that Georg Simmel — while writing about the dialectics of the German spirit and comparing it with the "shapelessness of 
the Russian essence" and the practicalism of the French and the English ("barbarity and lack of humaneness that they manifested in this war") — asserted that "individualism... is our pride and wealth... which is absolutely inseparable from German nature" (Simmel, 1917a: 34-35). While pondering the problems of a "folk psychology" ("Völker-Psychologie"), which defines the national character, Fritz Eulenburg, a disciple of Gustav Schmoller and professor of the Higher Technical School and Aachen, defined the primary thing that made Germans different from other European nations as the "German idealism" deeply rooted in them, which are underlain by "Gothic and German mysticism, Romanticism and German philosophy of the early $19^{\text {th }}$ century". Meanwhile, the "eastern soul" of Russians is shaped by the millenniumlong dominance of "Tatar serfdom" that was supported by the Orthodox church and tsarism; meanwhile, the English stand out for their distinctive rationality and "proclivity toward capitalistic entrepreneurship" (Eulenburg, 1917: 3).

The images of an English "merchant" and a German "hero" created in the famous pamphlet by sociologist and philosopher Werner Sombart The Merchant and the Hero gained the greatest popularity in the German humanities discourse and the public domain. The "merchant spirit" permeated all aspects of life in England, where the main things are individualism, practical gain, and benefit — "the benefit that everybody looks to gain as a result, which means as many riches as possible." And in this concept of life, the central place is occupied by material wealth, and respect is commanded only by economic activity, especially merchant business. Financial interest permeates all spheres of life, and in doing so, defines practical philosophy and utilitarian science. The "animalistic" ideal of utilitarians is "comfort and respectability: apple pie, Sunday mass, peace and quiet, football, a profitable business and a little spare time for a hobby." In the opinion of Werner Sombart, the English concepts of freedom and state serve the interests of commercialism and utilitarianism ("merchant worldview") exclusively, laying the groundwork for merchant business. Even the war is an exclusively commercial affair, which is why the English never gets dragged into hopeless battles because they are not familiar with the concept of heroism (Sombart, 1915: 14-64). The ideas of Werner Sombart were picked up by Prof. Arnold Schröer of the Higher Trade School in Cologne in his pamphlet On the Description of the English, in which the author mocked the eroticism of the English, their double moral standards, lying nature, superficial devoutness, practicality in day-to-day life, snobbish attitude toward neighbors, isolationism, war-mongering, etc. (Schröer, 1915).

\section{"Germanism" ("Deutschtums") and its Criticism}

The concept of "Germanism" ("Deutschtums") became a key philosophical category that substantiated the idea of "German freedom" in opposition to the English one. German philosophers put forward this concept as a result of their confidence that there existed a contemporary cultural crisis provoked by the realization of internal spiritual and intellectual differences by Western European nations and an optimistic confidence in the unifying concept of Western Europe (Lamprecht, 1914: 29-58). Future changes in Europe will stem from this feature, "which is why we must view and define German's future as exclusively German," Ernst Troeltsch contended. Meanwhile, this required deeper insights into German history with a special and productive perspective on the German state as a living spiritual unity. "Thousands are pondering the nature of Germanism today. We must know and understand history, but in and of itself, it never brings us to unity and the future. It can demonstrate only a beautiful and contradictory reality so long as it remains pure history ("Historie"). Unity is an ideal and work 
and creative efforts toward a common goal ("Zielrichtung"); in other words, it is an ambitious idea that - through immersion into the historical completeness of our life and our current state - leads to an idea-formulating intuition and can be corroborated by Freedom alone. This is exactly what constitutes the idea of Germanism that is currently being revived stronger than ever before, combining two key aspects of cultural and philosophical thought: a historicalempirical immersion and shaping of a sovereign ideal that stems from our confidence in the harmony of the world's creative freedom" (Troeltsch, 1916b: 46).

British intellectuals did not take long to answer this, and the differences between the national character of the English and Germans became the subject of a popular discourse in England. For one, English writer and translator Percy Ewing Matheson wrote ironically in his National Ideals brochure that Germans tried to convince the entire world that they were carriers of "culture," were in the vanguard of civilization. Their material resources are so well-organized that they deserve to be the school of Europe after the fashion of Ancient Greece. Without disputing the fact that the German organization of science is actually cutting-edge, the author contended that the English made substantial accomplishments in natural sciences. Meanwhile, German education manifested itself on the battlefield, where the German soldier proved to have no mercy for civilians. "The English soldier has been educated in a society where civil rights are supreme. He knows that he may be held responsible for his acts by the civil authority in time of peace, and his breeding has taught him that in war-time, he has a duty towards the weak and defenseless" (Matheson, 1915: 12). In the author's opinion, the chief ideas for the English are "freedom and justice", where freedom is individual freedom and constitutes the greatest accomplishment of the English over their entire history, promotes the spirit of entrepreneurship and growing well-being of every person, which is ensured by "justice", i.e. a legal system that makes everybody equal before the law. As for the word "gentleman," which German authors use ironically and derisively: "they are qualities which belong to no class, but to the nation: a readiness to take men on their merits, a sense of honor and of the duties of social position, a love of truth and honesty, a considerateness for the poor and weak, and that spirit of comradeship in danger and difficulty, which today, as in many past struggles, has been the vital strength of the British Navy and Army" (Matheson, 1915: 15-16).

The amorality of German foreign policy and army in the war served as evidence for British authors of the fact that the political systems of both countries were different. The cult of power that became established in Germany after 1871 actually suppressed individual freedom, while the conscience of a German citizen was shaped by state institutions where the idea of a "strong state" (a state that directed its efforts at capturing territories and enslaving other nations) substantiated by German theorists prevailed. Unable to accomplish this peacefully, Germany attempted to do so through violence. Meanwhile, England did not develop abstract political theories but instead implemented the idea of a civic nation - independence and equality of citizens before the law, influence of the civil society on political institutions, and choice of public policy. In a state like this, the views, feelings, and moral ideas of specific individuals greatly influence the state's policy (N. A., 1915: 88-89).

In 1917, when the outcome of the drawn-out war still could not be predicted, but Germany's successes on the frontline already seemed questionable, the tone of opinion-based journalistic publications of British intellectuals became even harsher. The political doctrine of "the strong is always right" was not merely criticized, but also took on a connotation that was openly disparaging toward Germans. "To the English mind the German political doctrine 
is so incredibly stupid that for many long years, while men in high authority in the German Empire, ministers, generals, and professors, expounded that doctrine at great length and with perfect clearness, hardly anyone could be found in England to take it seriously, or to regard it as anything but the vaporings of a crazy sect... The Germans have taken Antwerp; they may possibly destroy the British fleet, overrun England and France, repel Russia, establish themselves as the dictators of Europe - in short, fulfill their dreams. What then? At an immense cost of human suffering, they will have achieved, as it seems to us, a colossal and agonizing failure. Their engines of destruction will never serve them to create anything so fair as the civilization of France" (Raleigh, 1915: 5).

\section{Conclusions}

During World War I, it was important for British philosophers to debunk the myth about the greatness of German culture and philosophy, sine for many decades the British humanities discourse was dominated by a conviction that throughout the $19^{\text {th }}$ century Germany created a grand philosophy, literature, and culture as a whole, with many German ideas permeating their own works. This opinion also dominated in the social discourse. Another reason for the emphasized negative connotations in opinion-based journalism articles was the idea cultivated in Germany, according to which the German nation and army were united based on prior spiritual and cultural development. Hence the desire to demonstrate that this was exactly what provoked the origin of the spirit of "militarism."

The German humanities discourse was largely focused on the nation's internal problems and aimed to reinforce the "ideas of 1914" that created a distinctive illusion that the entire society rallied around the emperor. The popular discourse proposed an image of an English "merchant" as opposed to a German "hero" capable of sacrifice for the sake of the state and raised in German cultural and spiritual traditions.

The concept of a "culture crisis" formed an important set of topics for generating "negative templates" of perception by society of the "enemy image," along with the moral responsibility of German idealistic philosophy for the development of military nationalism and militarism in Germany (which Russian and British authors often equated). Whereas in Great Britain there was a predominantly negative attitude toward German philosophy, with efforts made to cultivate the formula "From Kant to Krupp" (which meant an evolution of the humanistic philosophy of the $18^{\text {th }}-19^{\text {th }}$ centuries toward a "philosophy of force" and demands to completely abandon its spiritual heritage), the scholarly discourse offered rather careful assessments of German idealism and even of Friedrich Nietzsche's philosophy. German philosophers attempted, on the one hand, to defend the intellectual contributions to the concept of an "ideal Europe" and, on the other hand, propagated the ideas of "Germanism" as a combination of the category of "individualism" of German Romanticism and idealism with a contemporary "distinctive German spirit."

\section{[D] References}

Archer, William (1915) Fighting a Philosophy. London, Edinburg. Hauptmann, Gerhart (1914) Gegen Unwahrheit. Berliner Tageblatts.Wochen-Ausgabe. 10. September: 7.

Hoeres, Peter (2004) Krieg der Philosophen. Die deutsche und britische Philosophie im Ersten Weltkrieg. Paderborn. 
Eulenburg, Fritz (1917) Völker-Psychologie, Berliner Tageblatts. Wochen-Ausgabe. 31. Juli: 3. Lamprecht, Karl (1914) Krieg und Kultur. Drei vaterländische Vortäge. Leipzig.

Matheson, Persy Ewing (1915) National Ideals. London, Edinburg.

Muirhead, John Henry (1915a). German Philosophy and the War. London: H. Milford, Oxford University Press.

Muirhead, John Henry (1915b). German Philosophy in Relation to the War. London.

N. A. (1915) British and German Ideals. The Meaning of the War. London.

Raleigh, Walter (1915) Might is Right. Oxford: Oxford University Press, Humphrey Milford.

Riebel, Alexander (2014) Die Philosophen im Krieg, Die Tagespost, 17. September 2014. URL: $\quad$ https://www.die-tagespost.de/gesellschaft/feuilleton/Die-Philosophen-imKrieg;art310,154988

Ringer, Fritz (2008) Zakat nemetskih mandarinov: Akademicheskoe soobschestvo v Germanii, 1890-1933. Moskva: Novoe literaturnoe obozrenie.

Schröer, Arnold (1915) Zur Charakterisirung der Engländer. Bonn.

Simmel, Georg (1917a) Die Dialektik des deutschen Geistes. Simmel Georg. Der Krieg und die geistigen Entscheidungen: Reden und Aufsätze. München und Leipzig, 31-41.

Simmel, Georg (1917b) Die Idee Europas, Simmel Georg. Der Krieg und die geistigen Entscheidungen: Reden und Aufsätze. München und Leipzig, 67-72.

Sombart, Werner (1915) Händler und Helden: Patriotische Besinnungen. München.

Troeltsch, Ernst (1916a). Die Ideen von 1914, Die neue Rundschau. Jg. 27: 605-624.

Troeltsch, Ernst (1916b). Über Maßtäbe zur Beurteilung Historischer Dinge, Historische Zeitschrift. 116 Bd.: 1-47. 